\title{
Phytochemical Screening and Antimicrobial Activity of Thyme vulgaris
}

\author{
Wafaa Alfadel Ahmed Almostafa and Mohammed Ibrahim Mohammed Adam* \\ College of Applied and Industrial Sciences, University of Bahri, Sudan \\ *Corresponding Author: Mohammed Ibrahim Mohammed Adam, College of Applied and Industrial Sciences, University of Bahri, Sudan.
}

Received: September 04, 2019; Published: September 16, 2019

DOI: 10.31080/ASMI.2019.02.0375

\section{Abstract}

This study was carried out in Khartoum State (Omdurman market), during December, 2017 in Thyme vulgaris which belong to family Lamiaceae locally known as ZATAR. The plant was chosen because of its using traditionally in treatment of many diseases.

Phytochemicals were investigated with aim to detect the antimicrobial effects of this plant. The dried leaves of Thyme vulgaris was extracted successively with (petroleum ether, chloroform, Methanol and Distell water).

The antimicrobial activity of extracts were evaluated against four standard bacteria(Gram positive; Bacillus subtilis, Staphylococcus aureus) and (Gram negative; Salmonella typhi, Pseudomonas aeruginosa).in addition of one standard fungi (Candida albicans).

The phytochemical screening carried out on different extracts of Thyme vulgaris and showed to contain high amount of alkaloids (acid and base ) with Distell water and petroleum ether, high amount of sterol (4+ in petroleum ether, distilled water and chloroform), and low amount of flavonoids, cardiac glycoside and tannins in Distell water, low amount of saponnins in all extracts.

The result of antimicrobial tests indicated that the Distell water and methanolic extracts inhibited the growth of all microorganisms.

The result provides promising baseline information for the potential use of these crude extracts in the treatment of bacterial and fungal infections.

Keywords: Thyme vulgaris; Screening; Antimicrobial Activity

\section{Introduction}

Medicinal plants

For centuries, medicinal plants have been used in different parts of the world as a source of both preventive and curative traditional medicine preparations for both human and livestock the traditional medicine also creates income to the indigenous people by exporting the dried form of the medicinal preparations [1]. The plants were used by people without knowledge of their active ingredients. The plant materials used include seeds, berries, roots, leaves, barks or flowers [2]. Those people took the crude extract orally, the practice which was extremely hazardous since the extracts may contain some toxic constituents [3]. They acquired knowledge of medicinal plants by methods of trial and error [4]. The indigenous people used the medicinal plants for medicine [5]. These medicinal plants consider as a rich resources of ingredients which can be used in drug development and synthesis. Besides that these plants play a critical role in the development of human cultures around the whole world.
For decades, due to the expansion and distribution of pests in new areas the use of chemical insecticides have been intensified which lead to serious hazards on man, animal and environment. This lead to intergraded pest management (IPM) which means the return to nature through the use of insecticides of plant origin to create balance in the ecosystem. In Sudan and worldwide intensive research for medical plants probably containing bio insecticides is going on to alleviate hazards of chemical insecticides. Medicinal plants have a promising future because there are about half million plants around the world, and most of them their medical activities have not investigate yet, and their medical activities could be decisive in the treatment of present or future studies.

\section{The main object}

The principle objective of the present study is to determine the activity of Thyme vulgaris leaves against different microorganism.

\section{Specific objectives}

- To compare physical and chemical properties of different extracts using differentsolvents. 
- To determine the antimicrobial and potential of Thyme vulgaris leaves against four bacterial species and one fungal species

\section{Material and Method}

All the chemicals and reagents used in this study were of analytical grade such as chloroform, distilled water, ethanol, methanol, petroleum ether, acetic anhydride, sulphuric acid, gelatine salt, ferric chloride, reagents (Wagner, Hager, and Dragendorffs), aluminium chloride and potassium hydroxide.

\section{Plant material, collection and identification}

Leaves of Thyme vulgaris collected in December 2017 from Omdurman, Khartoum state, Sudan and identified in herbarium of natural research Centre and compared with herbarium of Faculty of Science University of Khartoum.

\section{Preparation of crude extract}

$50 \mathrm{~g}$ of the dried plant were weighted and then extracted successively with petroleum ether by shaker apparatus for four hours at room temperature. The chloroform extract was filtrated then was air dried after extraction, the residual of the powdered plants materials were dried and then extracted again with methanol for 18 hours and the residual of the powdered were finally extracted with distill water each for 18 hours. The extracts were air dried between each extraction that has involved different solvents. Each extract was filtrated through Whitman No 1 filter paper, followed by concentrated under vacuum room. The crude extracts were then kept at $-20 \stackrel{\circ}{ } \mathrm{C}$ in sterile universal bottles.

\section{Phytochemical screening}

General phytochemical screening for the active constituents was carried out for extract using the methods carried by Shelley [6] and Akinyemi, Oladapo [7]. And for extract using the methods described by Martinez and Valencia [8]; Akinyemi., et al. [7].

\section{Antimicrobial activity preparation of culture media}

$28 \mathrm{~g}$ of powdered nutrient agar was weighted, dispersed in $1 \mathrm{li}-$ ter of distilled water and allowed to soak for 10 minutes, swirl to mix then sterilized by autoclaving for 15 minutes at 121c, cooled to $47 \mathrm{c}$, mixed well then poured into petridishes.

\section{Tested organisms bacterial organisms}

Bacillus subtitles (NCTC 8236 Gram positive bacteria). Salmonella typhi (ATCC 6538 Gram positive bacteria). Staphylococcus aureus (ATCC 25922 Gram negative bacteria). Pseudomonas arginosa (ATCC 27853 Gram negative bacteria).

\section{Fungal organisms}

Candida albicans (ATCC 7596 Fungi).
In vitro testing of extract for antimicrobial activity Testing for antibacterial activity

The cup-plate agar diffusion method [9] was adopted with some minor modifications to assess the antibacterial activity of the prepared extracts.

One $\mathrm{ml}$ of the standardized bacterial stock suspension $10^{8}-10^{9}$ C.F.U/ml were thoroughly mixed with $100 \mathrm{ml}$ of molten sterile nutrient agar which was maintained at $45 \mathrm{c}^{0} .20 \mathrm{ml}$ aliquots of the inoculated nutrient agar were distributed into sterile petri dishes. The agar was left to set and in each of these plate 4cups $(10 \mathrm{~mm}$ in diameter) were cut using a sterile cork borer (No.4) and agar disk were removed.

Alternate cups were filled with $0.1 \mathrm{ml}$ sample of each of the extract dilution in methanol using automatic microliter pipette, and allowed to diffuse at room temperature for two hours. The plates were then incubated in the upright position at $37 \mathrm{c}^{0}$ for 18 hours. Three replicates were carried out for each extract against each of the test organism. After incubation the diameters of the resultant growth inhibition zones were measured, averaged and mean values were tabulated.

\section{Testing for antifungal activity}

The same method for bacteria was adopted. Instead of nutrient agar. The incubated medium was incubated at $25 c^{0}$ for two days for the candida albicans.

\section{Result and Discussion}

Four solvents include petroleum ether $0.48 \%$ (green), followed by chloroform $3.06 \%$ (green), methanol $12.1 \%$ (crystal brown), and Distell water $4.98 \%$ (brown), were used in successive polarities to extract secondary metabolite from Thyme vulgaris (Table 1).

\begin{tabular}{|l|c|c|c|c|}
\hline $\begin{array}{c}\text { Solvent of } \\
\text { extraction }\end{array}$ & Characteristic & Color & Weight & $\begin{array}{c}\text { Yields } \\
\text { (\%) }\end{array}$ \\
\hline Petroleum Ether & Powder & green & 0.96 & 0.48 \\
\hline Chloroform & Powder & green & 6.12 & 3.06 \\
\hline Methanol & Crystal & brown & 24.2 & 12.1 \\
\hline Distilled Water & Powder & brown & 9.96 & 4.98 \\
\hline
\end{tabular}

Table 1: Result of extraction and physical properties.

Phytochemical screening of extract from Thyme vulgaris Leaves

The Phytochemical screening were carried out on different extracts of Thyme vulgaris and they showed to contain high amount of alkaloids (acid and base ) with Distell water and petroleum ether, high amount of sterol (4+ in petroleum ether, distilled water, chloroform) and low amount of flavonoids, cardiac glycoside and tannins in Distell water, low mount of saponnins in all extracts. 


\begin{tabular}{|c|c|c|c|c|}
\hline \multirow[t]{2}{*}{ Test/Solvent } & \multicolumn{4}{|c|}{ Successive method of extraction } \\
\hline & Petroleum ether & chloroform & Methanol & Distell water \\
\hline $\begin{array}{l}\text { Flavonoid } \mathrm{KoH} \mathrm{Alcl}_{3} \mathrm{NH}_{3} \mathrm{OH} \\
\mathrm{Mg}\end{array}$ & $\begin{array}{l}+ \\
+ \\
+ \\
-\end{array}$ & $\begin{array}{l} \\
- \\
- \\
-\end{array}$ & $\begin{array}{l} \\
- \\
- \\
-\end{array}$ & $\begin{array}{c}++ \\
++ \\
- \\
-\end{array}$ \\
\hline $\begin{array}{l}\text { Tannin } \\
\text { Ferric chloride Gelatin }\end{array}$ & + & - & $\begin{array}{l}+ \\
+\end{array}$ & $\begin{array}{l}++ \\
++\end{array}$ \\
\hline $\begin{array}{l}\text { Alkaloid (Base) Hager Drangendroff } \\
\text { Wagner } \\
\text { Mayer }\end{array}$ & $\begin{array}{l}++++ \\
++++ \\
++++ \\
++++\end{array}$ & $\begin{array}{l}++ \\
++ \\
++ \\
++\end{array}$ & $\begin{array}{l}- \\
- \\
- \\
-\end{array}$ & $\begin{array}{l}+ \\
+ \\
+ \\
-\end{array}$ \\
\hline $\begin{array}{l}\text { Alkaloid(Acid) Hager } \\
\text { Drange droff Wagner Mayer }\end{array}$ & $\begin{array}{l}- \\
- \\
- \\
-\end{array}$ & $\begin{array}{l}- \\
- \\
- \\
-\end{array}$ & $\begin{array}{l}++ \\
++ \\
++ \\
++\end{array}$ & $\begin{array}{l}++++ \\
++++ \\
++++ \\
++++\end{array}$ \\
\hline $\begin{array}{l}\text { Tirterpenes/sterol Lieberman } \\
\text { Salkowski }\end{array}$ & $\begin{array}{l}++++ \\
++++\end{array}$ & $\begin{array}{c}+++ \\
++\end{array}$ & $\begin{array}{l}+ \\
+\end{array}$ & $\begin{array}{l}++++ \\
++++\end{array}$ \\
\hline Coumarins KoH/UV & - & - & - & - \\
\hline Saponins Foam & ++ & ++ & ++ & ++ \\
\hline Glycoside Anthraquinone & - & - & - & - \\
\hline Cardic glucoside & + & + & + & ++ \\
\hline
\end{tabular}

Table 2: Results of phytochemical screening of Thyme vulgaris Leaves.

Key: ++++: High Amount, +++: Moderate Amount, ++: Low Amount , +: Trace Amount, -: Not Found

The extract of Thyme vulgaris Leaves at concentrations $(100 \mathrm{mg} /$ $\mathrm{ml}, 50 \mathrm{mg} / \mathrm{ml}, 25 \mathrm{mg} / \mathrm{ml}$ ), were subjected to antimicrobial tests by using cup plate agar diffusion method and inhibition zone were measured in ( $\mathrm{mm}$ ) against four bacterial species and one fungi. The range of inhibition was found $11-25 \mathrm{~mm}$ (Table 3). The distilled water extract showed high inhibition zone against all tested microorganisms. At the same time the chloroform and petroleum ether has no inhibition zone against all tested microorganism.

\begin{tabular}{|c|c|c|c|c|c|c|}
\hline \multicolumn{1}{|c|}{ Extract } & Concentrations & Sal & P.s & B.s & S.a & C.a \\
\hline Distell water & 100 & 20 & 22 & 25 & 19 & 18 \\
& 50 & 16 & 17 & 17 & 16 & 13 \\
& 25 & 15 & 16 & 16 & 15 & 12 \\
& 12.5 & 13 & 15 & 15 & 13 & 11 \\
\hline \multirow{5}{*}{ Methanol } & 6.25 & 11 & 13 & 14 & 11 & - \\
& 100 & 20 & 20 & 20 & 20 & 19 \\
& 50 & 14 & 13 & 16 & 12 & 17 \\
& 25 & 13 & 11 & 14 & 11 & 16 \\
& 12.5 & - & - & - & - & 15 \\
& 6.25 & - & - & - & - & 12 \\
\hline Chloroform & 100 & - & - & - & - & - \\
& 50 & - & - & - & - & - \\
& 25 & - & - & - & - & - \\
& 12.5 & - & - & - & - & - \\
& 6.25 & - & - & - & - & - \\
\hline
\end{tabular}




\begin{tabular}{|l|c|c|c|c|c|c|}
\hline Petroleum & 100 & & & & & \\
ether & 50 & & & & \\
& 25 & - & - & - & - & \\
& 12.5 & & & & & \\
& 6.25 & & & & & \\
\hline
\end{tabular}

Table 3: Results of antimicrobial activities.

Key: B.s: Bacillus subtilis; S.a: Staphylococcus aureus; P.a: Pseudomonas aeruginosa; Sal: Salmonella typhi; C.a: Candida albicans concentration of extract $(100,50,25,12.5,6.25)$.

Thyme vulgaris Leaves extracts properties and yield

Four solvents were used in successive extractable method distilled water gave generally higher extractability than those obtain from (petroleum ether, chloroform, methanol).

In case of petroleum ether, chloroform the consistency of extractable material seem to be green powder, with differences in yield, and the extract of distilled water seem to be brown powder.

Methanol it is high extractability than all others it is brown crystal.

Variation was observed in the colours of extract may be were reflection to type of solvent ingredients of plant.

\section{Phytochemical screening of Thyme vulgaris Leaves}

Phytochemical screening of chemical constituents of Thyme vulgaris leaves extracts, flavonoids were present in low amount in distlled water and trace amount in petroleum ether.

Moreover all extract contain low amount of saponnin. Where Alkaloid present in high amount in Distilled water, petroleum ether and low amount in chloroform and methanol.

Sterol present in high amount in all extract except methanol trace amount. In addition cardiac glycosides were found in trace amount in all extract except distilled water low amount.

The extracts of methanol results disagree to [10]. This difference may due to the condition of the experiments or well as differences in methodology of extraction, in variation of amount of secondary metabolites.

\section{Antimicrobial activities of Thyme vulgaris leaves}

The distilled water showed different activity at all concentrations $(100,50,25,12.5,6.25)$ against the clinical of Salmonella $(20,16,15,13,11)$, respectively as well as for Pseudomonas arginosa $(22,17,16,15,13)$, Bacillus subtitles $(25,17,16,15,14)$, and show low activity against Staphylococcus aureus $(19,16,15,13)$ and against Candida albicans.
Methanol was showed as against Salmonella $\left(20,14,13\right.$, __-_ $_{1}$, Pseudomonas arginosa $\left(20,13,11, \_\right.$,_, Bacillus subtitles $\left(20,16,14\right.$, ___-_ $\left._{2}\right)$, Candida albican $(19,17,16,15,12)$, and showed low amount against Staphylococcus aureus $\left(20,12.11\right.$, ____ $\left._{2}\right)$.

Petroleum ether and chloroform has no inhibition zone against tested all microorganisms.

This compared with assays reported by Syed Inayatullah., et al. [11] essential oil extract of Thyme vulgaris leaves was found effective against all tested Gram positive and Gram negative bacteria inhibition zone (range between 11-25mm).

Distell water extract of Thyme vulgaris leaves was found effective against all tested bacteria. Where methanol extract of Thyme vulgaris leaves was active against Gram positive and Gram negative bacteria at specific concentrations.

\section{Conclusion}

Antimicrobial resistance is reported to be on the increase due to gene mutation of the disease pathogens. Thyme vulgaris was chosen for this study because of their reputation in traditional medicine as antimicrobial agents and usage in many diseases.

Phytochemical screening was carried out and lead to presence of some secondary metabolites the plant was showed to contain alkaloids, flavonoids, tannins, saponnins, sterol, Triterpenes, cardiac glycosides.

The crude extracts were subjected to antimicrobial assays using cup plate diffusion method and the inhibition zone was measured in $\mathrm{mm}$.

The methanol and Distell water extracts gave good result against all tested microorganisms (Sal, P.a, S.a, B.s, and C.a).

The chloroform and petroleum ether extracts showed absence of inhibition zone against all tested microorganisms. 


\section{Bibliography}

1. Yirga, G. "Assessment of traditional medicinal plants in Endrta district, South-eatern Tigray, Northern Ethiopia". African Journal of Plant Science 4.7 (2010): 255-260.

2. Oreagba IA., et al. "Herbal medicine use among urban residents in Lagos, Nigeria". BMC Complementary and Alternative Medicine 11 (2011): 117.

3. Egwaikhinde PA., et al. "Screening for antimicrobial activity and phytochemical constituents of some nigerian medicinal plants". Journal of traditional Medicinal Plants Research 3.12 (2009): 1088-1091.

4. Okigbo RN., et al. "Biodiversity and conservation of medicinal and aromatic plants in Africa". Biotechnology and Molecular Biology Reviews 3.6 (2008): 127-134.

5. de Boer HJ., et al. "Antifungal and antibacterial activity of some herbal remedies from Tanzania”. Journal of Ethnopharmacology 96 (2005): 461-46.

6. Shelley BC. "Ethanobotany and the process of drug discovery: a laboratory exercise". The American Biology Teacher 71.9 (2009): 541-547.

7. Akinyemi K O., et al. "Screening of crude extracts of six medicinal plants used in South West Nigerian unorthodox medicine for anti-methicillin resistant Staphylococcus aureus activity". BMC Complementary and Alternative Medicine 5.1 (2005): 1.
8. Martinez A and Valencia G "Marchafitoquimica". In Manual deprácticas de Farmacognosia y Fitoquímica: 1st edition. Medellin: Universidad de Antioquia (2003) (1999): 59-65.

9. Kavanagh F. "Analytical Microbiology". In: Kavanagh, F., Academic Press, New York \& London 11 (1972).

10. Boruga O., et al. Department of Ophthalmology, Department of Food Science, Faculty of Food Processing Technology, Banat's university of Agricultural Sciences and Veterinary Medicine, Timișoara, Romania. Journal of Medicine and Life 7.3 (2014).

11. Syed Inayatullah., et al. "Department of Biotechnology". International Journal of Biosciences 10.2 (2017): 105-110.

Volume 2 Issue 10 October 2019

(C) All rights are reserved by Wafaa Alfadel Ahmed Almostafa and Mohammed Ibrahim Mohammed Adam. 